\title{
Experimentación y simulación numérica de tubos de hormigón con fibras
}

\section{Experimentation and numerical simulation of steel fibre reinforced concrete pipes}

\author{
A. de la Fuente ${ }^{(*)}$, A. Domingues de Figueiredo(**), A. Aguado(*), C. Molins(*), P. J. Chama Neto(**)
}

Recepción/Received: 7-X-10

Aceptación/Accepted: 22-XI-10

Publicado online/Online publishing: 10-XII-10

RESUMEN

En este artículo se presentan los resultados principales de un estudio experimental y numérico del comportamiento de tubos hormigón reforzado con fibras de acero (THFA). Se fabricaron y ensayaron 18 tubos de $600 \mathrm{~mm}$ de diámetro con cuantías de 10,20 y $40 \mathrm{~kg} / \mathrm{m}^{3}$ de fibras, concluyéndose varios aspectos tecnológicos relacionados con la fabricación y el ensayo así como del comportamiento resistente. Por otra parte, se ha desarrollado el modelo numérico MAP que permite la simulación del comportamiento resistente de THFA sometidos al ensayo de aplastamiento. Los resultados han sido satisfactorios para cualquier régimen de carga, permitiendo concluir que el modelo es una herramienta útil para el diseño óptimo de este tipo de tubos. Se concluye que el uso del modelo conduce a una reducción del coste del armado y da un impulso al uso de fibras como elemento de refuerzo en esta tipología estructural

Palabras clave: tubos de hormigón, fibras de acero, ensayo de aplastamiento y fisuración.

\begin{abstract}
SUMMARY
The results concerning on an experimental and a numerical study related to SFRCP are presented. Eighteen pipes with an internal diameter of $600 \mathrm{~mm}$ and fibre dosages of 10,20 and $40 \mathrm{~kg} / \mathrm{m}^{3}$ were manufactured and tested. Some technological aspects were concluded. Likewise, a numerical parameterized model was implemented. With this model, the simulation of the resistant behaviour of SFRCP can be performed. In this sense, the results experimentally obtained were contrasted with those suggested by means MAP reaching very satisfactory correlations. Taking it into account, it could be said that the numerical model is a useful tool for the optimal design of the SFRCP fibre dosages, avoiding the need of the systematic employment of the test as an indirect design method. Consequently, the use of this model would reduce the overall cost of the pipes and would give fibres a boost as a solution for this structural typology.
\end{abstract}

Keywords: concrete pipes, steel fibres, crushing test, cracking.

\footnotetext{
(*) Universitat Politécnica de Catalunya (Barcelona, España).

(**) Escola Politécnica, USP (Brazil).
} 


\section{INTRODUCCIÓN}

Los tubos de hormigón armados con armadura tradicional (THA) y los tubos de hormigón con fibras de acero (THFA) son alternativas conocidas y empleadas para el transporte de agua, residuos industriales, saneamiento entre otros (1-4). Para éstos, la adición de fibras conduce a ventajas tanto técnicas, mejorando las propiedades mecánicas del hormigón (5), como económicas (2). Si se emplean además barras de acero, éstas desempeñan la tarea resistente principal (6) mientras que las fibras activan un mecanismo de puente entre los labios de las fisuras que conduce a una reducción de su separación y de su apertura (7). Desde la vertiente económica, el ahorro de armadura tradicional se traduce en una disminución de las operaciones de montaje, mano de obra, maquinaria, así como de los riesgos asociados (2).

El uso de fibras para el refuerzo de tubos de hormigón (TH) no es reciente, sino que su desarrollo se inició hace prácticamente dos décadas. No obstante, su introducción en el mercado está siendo progresiva a causa de factores como riesgo de cortes durante las tareas de manipulación, falta y/o desconocimiento de métodos de cálculo para abordar el diseño de estos elementos y, por último, la tradicional inercia al cambio (8).

Sin embargo, con el transcurso de los años, se ha podido dar respuesta a la mayor parte de la problemática presentada anteriormente: aplicación de un fratasado y un pulido para eliminar las imperfecciones y evitar los posibles cortes, ecuaciones constitutivas para considerar la contribución a tracción del hormigón con fibras (9-11) y, además, se ha comprobado que la incorporación de fibras mejora la respuesta en servicio de la tubería y conduce a una reducción global de los costes $(2,8)$.

Con el fin de ahondar en aspectos tanto tecnológicos como de simulación, se han desarrollado varias campañas experimentales conjuntas entre la Universidad de São Paulo $(4,12)$ y la Universidad Politécnica de Catalunya (2). En referencia a los primeros, se ha trabajado en el procedimiento a seguir para ejecutar el ensayo de aplastamiento (EA) de acuerdo con (13). Se ha corroborado que el ensayo continuo es representativo del comportamiento post-rotura de los THFA, tal como se verificó en (3). Asimismo, se ha analizado la influencia en los resultados el llevar a cabo las medidas en sólo en un extremo del tubo o en ambos durante la ejecución de EA. Simultáneamente, se ha desarrollado Model for the Analysis of Pipes (MAP) para la simulación de la respuesta mecánica de tubos de hormigón en masa (THM), THA y THFA. Con este modelo se pretende, por una parte, contrastar los resultados experimentales con los derivados del mismo y, por otra, proporcionar una herramienta numérica que permita el diseño óptimo del armado para este tipo de tubos.

\section{INTRODUCCIÓN}

Steel bar reinforced concrete pipes (SBRCP) and steel fibre reinforced concrete pipes (SFRCP) are well-known alternatives used for the conveyance of water, industrial wastes, sewerage among other applications (1-4). The addition of fibres to these pipes leads to the improvement of mechanical properties of concrete (5), as well as to economic savings (2). When steel rebars are also used, they perform the main resistance task (6), whereas the fibres activate a bridging mechanism between the cracks which leads to a reduction of their separation and opening (7). From an economic point of view, the saving of the traditional reinforcement results in a reduction of assembling operations, labour force and machinery, as well as in a decrease in the risks associated to manufacturing (2).

The use of fibres as reinforcement of concrete pipes (CP) is not a recent practice; in fact, its development began practically two decades ago. Nevertheless, its introduction into the market has been progressive, due to factors such as the risk of cuts during the manipulation tasks, lack of knowledge on design and calculation methods and, finally, the traditional inertia towards change (8).

However, through the years, solutions have been found for most of the problems previously mentioned: application of polishing so as to eliminate imperfections and avoid damages, constitutive equations to consider the tensile strength contribution of fibres in the concrete matrix (9-11) and, furthermore, it has been proved that the addition of fibres improves the mechanical behaviour of the pipe and leads to a global reduction of the costs $(2,8)$.

With the purpose of examining technological and simulation aspects in detail, several experimental campaigns have been developed between the University of São Paulo $(4,12)$ and the Polytechnic University of Catalonia (2). As regards the former, the work carried put concerns the procedure to follow to implement the crushing test (CT) in accordance with (13). In this sense, it was also corroborated that the continuous test is representative of the post-failure behaviour of the SFRCP, as was verified in (3). Likewise, the influence of measuring in only one of the ends of the pipe or in both ends during the execution of the CT in the results was also analyzed. Simultaneously, the Model for the Analysis of Pipes (MAP) was developed for the simulation of the mechanical response of plain concrete pipes $(P C P)$, $S B R C P$, and SFRCP. This model aims, on the one hand, at contrasting the experimental results with those derived from the model and, on the other hand, at providing a numerical tool that enables the design of the optimal reinforcement for this type of pipes. 
En definitiva, el objetivo de este artículo consiste en presentar la campaña experimental realizada para tubos de $600 \mathrm{~mm}$ de diámetro con $\mathrm{C}_{\mathrm{f}}$ de 10,20 y $40 \mathrm{~kg} / \mathrm{m}^{3}$, citar las bases del modelo MAP y en contrastar los resultados numéricos con los experimentales con el fin de valorar la bondad del modelo como herramienta para diseño optimo de THFA.

\section{FABRICACIÓN DE LOS TUBOS}

Para la campaña experimental se fabricaron, en 2 series distintas, un total de 18 THFA de $600 \mathrm{~mm}$ de $D_{i}$ y un $\mathrm{h}$ de $72 \mathrm{~mm}$. Los valores de $C_{f}$ empleados fueron de 10, 20 y $40 \mathrm{~kg} / \mathrm{m}^{3}$, fabricándose 3 tubos con cada cuantía.

Con el fin de evitar la influencia de la variable temporal, los tubos correspondientes a cada una de las 2 series se fabricaron el mismo día, empleándose en todos los casos, el cemento y los áridos habituales de la planta de producción en la que se ejecutaron (ver Tabla 1). Se utilizaron fibras metálicas DRAMIX ${ }^{\circledR}$ RC-80/60-BN. En la 1a serie se observaron algunos problemas durante el amasado y el vertido a causa de la pérdida de docilidad a la que conduce el empleo de fibras (14). Estos problemas se corrigieron en la $2^{\mathrm{a}}$ serie mediante un aumento de la cantidad de agua con el incremento de $C_{f}$. De este modo, se logró un nivel de acabados excelente y una mayor velocidad de producción.
Summarizing, the goal of this article consists in introducing the experimental campaign carried out with pipes with an internal diameter of $600 \mathrm{~mm}$ and $C_{f}$ of 10, 20 and $40 \mathrm{~kg} / \mathrm{m}^{3}$, mentioning the bases of the MAP model, and contrasting the numerical results with the experimental ones in order to assess the suitability of the model as a tool for the optimal design of SFRCP.

\section{PRODUCING PIPES}

For the experimental campaign, a total of 18 SFRCP with a $D_{i}$ of $600 \mathrm{~mm}$ and a $h$ of $72 \mathrm{~mm}$ were manufactured, in two different series. The values of $C_{f}$ used were 10, 20 and $40 \mathrm{~kg} / \mathrm{m}^{3}$, and 3 pipes were manufactured with each of the amounts.

In order to avoid the influence of the temporal variable, the pipes corresponding to each of the two series were manufactured on the same day, using in all cases the usual cement and aggregates at the manufacturing plant where they were produced (see Table 1). DRAMIX ${ }^{\circledR} R C$ $80 / 60-B N$ metallic fibres were used. In the $1^{\text {st }}$ series there were some problems during the mixing and pouring, due to the loss of workability triggered by the addition of fibres (14). These problems were corrected in the $2^{\text {nd }}$ series increasing the water content with the increase of $C_{f}$. In this way, an excellent finish level and a higher production speed were achieved.

Tabla 1 / Table 1

Dosificación empleada para la fabricación del HRFA.

Dosages used for manufacturing the SFRCP.

\begin{tabular}{|c|c|}
\hline Material / Material & Dosificación / Dosage \\
\hline Arena de río / River Sand $\left(d_{\max }=1.2 \mathrm{~mm}\right)$ & $679 \mathrm{~kg} / \mathrm{m}^{3}$ \\
\hline Arena de machaqueo / Crushed Sand $\left(d_{\max }=4.8 \mathrm{~mm}\right)$ & $340 \mathrm{~kg} / \mathrm{m}^{3}$ \\
\hline Árido de machaqueo / Crushed Coarse Aggregate $\left(d_{\max }=9.5\right)$ & $1067 \mathrm{~kg} / \mathrm{m}^{3}$ \\
\hline Cemento / Cement & $355 \mathrm{~kg} / \mathrm{m}^{3}$ \\
\hline Agua / Water & $152 \mathrm{l} / \mathrm{m}^{3}$ \\
\hline Fibras / Fibres & $10,20 \mathrm{y} 40 \mathrm{~kg} / \mathrm{m}^{3}$ \\
\hline
\end{tabular}

Las fibras se añadieron directamente en la cinta transportadora y el hormigón se compactó mediante el método de la vibro compresión (2). Los tubos fueron posteriormente transportados y almacenados en el patio de acopio de la fábrica hasta la fecha de ensayo (28 días).

\section{EL ENSAYO DE APLASTAMIENTO PARA THFA}

\subsection{Procedimiento según la UNE-EN 1916:2002}

El EA (ver Figura 1) consiste en la aplicación de una carga longitudinal uniformemente distribuida sobre la generatriz superior del tubo, estando éste apoyado sobre dos aristas
The fibres were added directly in the conveyor belt and the concrete was compacted by means of the vibrocompression method (2). The pipes were subsequently transported and stored at the stocking area of the factory until the test date (28 days).

\section{CRUSHING TEST FOR SFRCP}

\subsection{Procedure according to UNE-EN 1916:2002}

The CT (see Figure 1) consists in the application of a longitudinal load distributed uniformly over the upper generatrix of the pipe, which is supported on two edges 
que forman un ángulo de valor $2 \beta$ respecto al centro del tubo (O). En (15) se especifica el procedimiento a seguir en la ejecución para THFA:

1. Resistir la carga $F_{c}$ durante un minuto sin que aparezcan fisuras, o lo que es lo mismo: sin que se alcance la carga $\mathrm{F}_{\mathrm{cr}}$, siendo $\mathrm{F}_{\mathrm{c}}$ igual o superior al $67 \%$ de la carga $F_{n}$.

2. Llevar el tubo hasta rotura, obteniéndose la carga $F_{\mathrm{u}}$ que debe ser superior $a F_{n}$.

3. Cuando la carga desciende un $5 \%$ de $F_{u}$, se descarga el tubo y se recarga verificándose que se alcanza una carga $F_{\text {min,pos }}$ no inferior al $67 \%$ de $F_{n}$. Ésta debe mantenerse al menos un minuto.

El proceso cíclico tiene como misión verificar que el anclaje fibra-hormigón y la resistencia post-pico del HRFA son las adecuadas para garantizar la $F_{\text {min,pos. }} \mathrm{Si}$ bien, en (3) se demostró que el ensayo continuo garantiza resultados representativos y fiables de la respuesta resistente del tubo. forming an angle with value $2 \beta$ with regard to the centre of the pipe $(O)$. The procedure to follow for the execution of the CT for SFRCP is specified in (15):

1. Withstanding load $F_{C}$ for a minute without cracking, or in other words: without reaching load $F_{c r}, F_{c}$ being equal or higher than the $67 \%$ of load Fn.

2. Leading the pipe to failure, obtaining load $F_{u}$ (higher than $F_{n}$ ).

3. Unloading and reloading the pipe when the load decreases a $5 \%$ of $F_{u}$ verifying that a load $F_{\text {min,pos }}$ not lower than the $67 \%$ of $F_{n}$ is reached. This must be maintained at least for a minute.

The intention of the cyclical process is verifying that the fibre-concrete anchorage and the post-cracking strength of SFRC are suitable for guaranteeing $F_{\text {min,pos, }}$ even though it was already proved in (3) that the continuous test leads to representative and reliable results of the resistance response of the pipe.

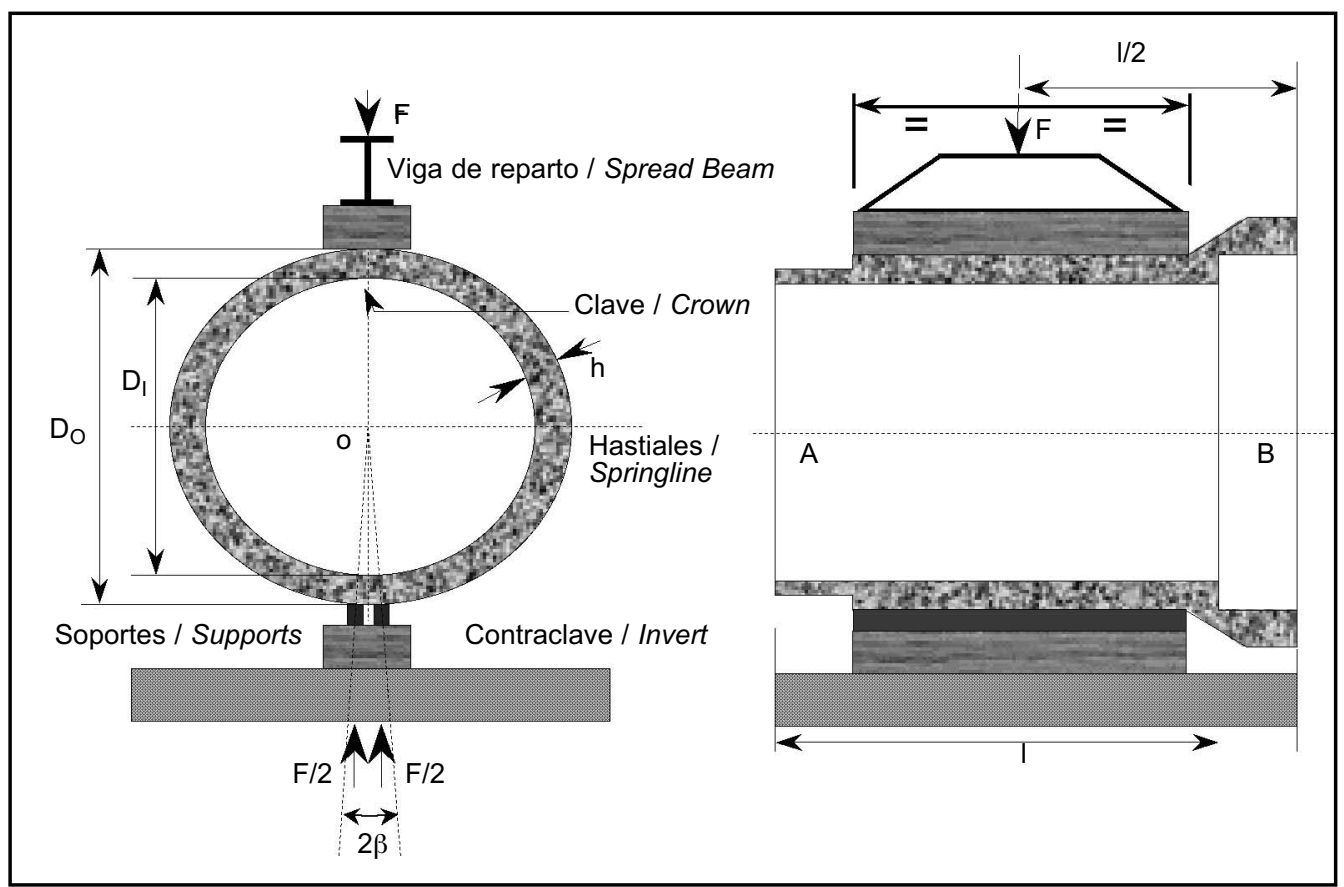

Figura 1. (a) Sección transversal y (b) sección longitudinal del EA.

Figure 1. (a) Cross and (b) longitudinal sections of the test configuration.

\subsection{Procedimiento de medida adoptado}

Para hacer posible la realización de los ensayos de forma continua con suficiente precisión, es necesario implantar dispositivos que permitan la medición ininterrumpida de v (12). Se emplearon LVDTs adheridos en la cara interna de la clave del tubo y fijados en la contraclave. Éstos descargaron los datos a un equipo informático y se procesaron para obtener las curvas F-v.

\subsection{Measuring procedure}

In order to carry out the tests with enough accuracy, it was necessary to use a device that enables the uninterrupted measurement of $v(12)$. LVDTs were used: they were stuck to the internal face of the key of the pipe and fixed in the invert. They transferred the data to a computer which processed them to obtain the $F-v$ curves. 
Para la medida de $v$ se utilizaron dos configuraciones ( $1^{\mathrm{a}}$ serie y $2^{\mathrm{a}}$ serie). En la $1 \mathrm{a}$ serie, se midió $\mathrm{v}$ en los dos extremos del tubo (secciones A y B de la Figura 1b), siendo el valor medio la deformación resultante adoptada; mientras que, en la 2a serie, se midió sólo en la sección A (ver Figura 1b).

\section{RESULTADOS EXPERIMENTALES}

En la Figura 2 se presentan las medias las curvas F-v para cada $C_{f}$ obtenidas en las dos series (valores de $v$ hasta los $4 \mathrm{~mm}$ para los tubos de la $1^{\text {a }}$ serie y hasta los $8 \mathrm{~mm}$ para los de la $2^{\mathrm{a}}$ ). Las curvas F-v de cada ensayo individual se presentan y analizan en el apartado de contrastación experimental-numérica.

En general, tal como se muestra en la Figura 2, se observa un patrón de comportamiento de reblandecimiento bien definido para los tubos con bajas cuantías de fibras; es decir, se producía una pérdida de capacidad resistente del tubo con el aumento de $v$ una vez alcanzada la carga $F_{\mathrm{u}}$. Contrariamente, los tubos con $40 \mathrm{~kg} / \mathrm{m}^{3}$ respondieron de forma distinta, presentando endurecimiento al alcanzar el punto de plastificación (punto $Y$ e $Y^{*}$ de la Figura 2 para los tubos con $40 \mathrm{~kg} / \mathrm{m}^{3}$ de la $1^{\mathrm{a}}$ y $2^{\mathrm{a}}$ serie, respectivamente). En consecuencia, los v requeridos para detectar el decremento de $\mathrm{F}$ que indica la rotura del elemento y el régimen post-rotura, no se alcanzan en los ensayos llevados a cabo.

De dicha Figura 2 se desprende también que los tubos de la $1^{\text {a }}$ serie presentan una mayor rigidez y una primera fase de comportamiento más prolongada. Ello se debe a que la sección $\mathrm{B}$ (Figura $1 \mathrm{~b}$ ) es más rígida que la $\mathrm{A}$ (Figura 1b) a causa del mayor volumen de hormigón involucrado y el mayor $D_{i}$ de la primera. Por lo tanto, teniendo en cuenta que se trabaja con el valor medio de $v$ en los tubos de la 1a serie, es razonable que éstos presenten una mayor rigidez en comparación con los de la $2^{a}$, para los que sólo se midió v en la zona A.
For the measurement of $v$, two configurations were used ( $1^{\text {st }}$ series and $2^{\text {nd }}$ series). In the $1^{\text {st }}$ series, $v$ was measured in the two edges of the pipe (sections $A$ and $B$ in Figure $1 b$ ), the average value being the resulting displacement adopted; whereas in the $2^{\text {nd }}$ series $v$ was only measured in section A (see Figure $1 b$ ).

\section{EXPERIMENTAL RESULTS}

Figure 2 shows the average of the F-v curves for each $C_{f}$ obtained in the two series (values of $v$ up to $4 \mathrm{~mm}$ for pipes from the $1^{\text {st }}$ series and up to $8 \mathrm{~mm}$ for those from the $2^{\text {nd }}$ series). The F-v curves from each individual test are presented and analyzed in the experimentalnumerical contrasting section.

As it can be observed, Figure 2 shows a well-defined softening behaviour pattern in the case of pipes with low amounts of fibres; in other words, the pipe undergoes a loss of resistance capacity with the increase of $v$ once load $F_{u}$ was reached. On the other hand, the pipes with $40 \mathrm{~kg} / \mathrm{m}^{3}$ respond differently, showing hardening when the yielding point is reached (points $Y$ and $Y^{*}$ from Figure 2 for the pipes with $40 \mathrm{~kg} / \mathrm{m}^{3}$ from the $1^{\text {st }}$ and $2^{\text {nd }}$ series, respectively). Consequently, the $v$ required in order to detect the decrease of $F$ which indicates the failure of the element and the post-failure regime are not reached in this sort of pipes.

From Figure 2 it is also deduced that the pipes in the $1^{\text {st }}$ series show higher stiffness and a longer uncracked stage. This happens because section $B$ (Figure $1 b$ ) is stiffer than section $A$ (Figure $1 b$ ) due to the higher volume of concrete involved and to the higher $D_{i}$ of the former. Therefore, taking into account that the average value of $v$ is accepted for the pipes of the $1^{\text {st }}$ series, it is reasonable they show higher stiffness in comparison to those from the $2^{\text {nd }}$ series, for which $v$ was only measured in section $A$.

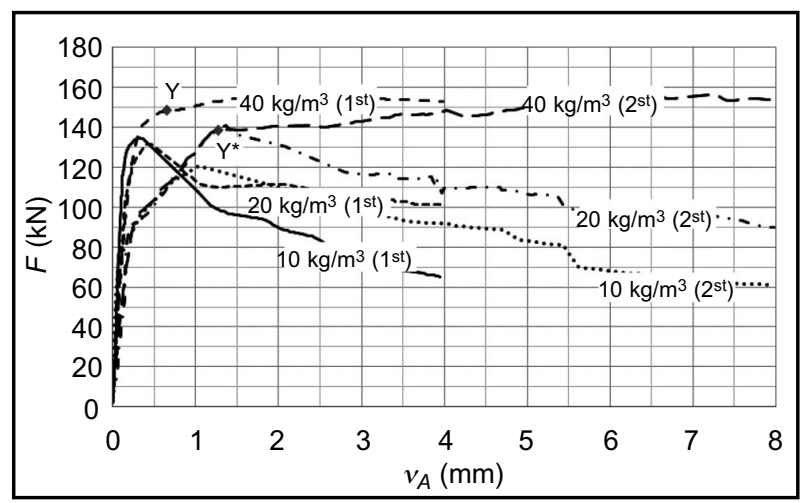

Figura 2. Curvas F-v medias de los tubos ensayados.

Figure 2. Average F-v curves obtained for the tested pipes. 
En relación con este aspecto, se observó que la fisuración se iniciaba en todos los casos en la clave de la sección A para valores de Fcr del entorno de los $90 \mathrm{kN}$. Por otro lado, en los tubos de la $2^{\mathrm{a}}$ serie se apreciaba que la aparición de las primeras fisuras coincidía con el cambio de pendiente de la curva F-v. Este cambio no se detectó en los tubos de la $1^{a}$ serie hasta que fisuraron también los hastiales, situación que se produjo cuando la carga $\mathrm{F}$ alcanzó valores medios de 126 kN, 114 kN y 138 kN para los tubos con $10 \mathrm{~kg} / \mathrm{m}^{3}, 20 \mathrm{~kg} / \mathrm{m}^{3}$ y $40 \mathrm{~kg} / \mathrm{m}^{3}$, respectivamente. Así pues, se puede afirmar que si la medida de $\checkmark$ se lleva a cabo en la sección $A$, la carga $F_{c r}$ se puede deducir de la curva F-v en el punto donde se produce el primer cambio brusco de pendiente. Contrariamente, si la medida se lleva a cabo como en la $2^{a}$ serie, este procedimiento conduciría a valores de $\mathrm{F}_{\mathrm{cr}}$ del lado de la inseguridad, requiriéndose una inspección visual para detec$\operatorname{tar} \mathrm{F}_{\mathrm{cr}}$.

Para los tubos con $\mathrm{C}_{\mathrm{f}}$ bajas se observaron regiones de inestabilidad semejantes a las descritas en (3). Éstas, se plasman en las curvas F-v mediante un aumento de la distancia entre puntos (ver tramo comprendido entre los 1,5 y $3,0 \mathrm{~mm}$ de los tubos con $20 \mathrm{~kg} / \mathrm{m}^{3}$ de la $2^{\mathrm{a}}$ serie, por ejemplo).

Asimismo, se verificó que los tubos alcanzaban los requisitos resistentes de la clase C-90 fijados en (15). En este caso, para el $D_{i}$ de $600 \mathrm{~mm}$ se exige que los tubos obtengan en el EA una carga $F_{C}$ de $36 \mathrm{kN} / \mathrm{m}$, tanto en régimen pre-fisuración como en post-rotura, y una carga $F_{\mathrm{u}}$ de 54 $\mathrm{kN} / \mathrm{m}$. Atendiendo a que la longitud de los tubos es de $2.500 \mathrm{~mm}$, resulta que dichas cargas son de $90 \mathrm{kN}$ y $135 \mathrm{kN}$, respectivamente.

En referencia a la carga $F_{\text {min,pos }}$ establecida para la C-90 (90 kN), debe verificarse que la $F_{\text {max, pos }}$ medida en la curva F-v es superior o igual a la primera. El valor de $v$ para el cual se da $F_{\text {max,pos }}$ es función, entre otras, del diámetro del tubo y de la cuantía y tipo de armadura; en definitiva, de la rigidez global del tubo. Para este trabajo, se ha establecido que $F_{\text {max } \text {,pos }}$ se alcanza para un $v$ de $1,2 \mathrm{~mm}\left(F_{1.2 \mathrm{~mm}}\right)$ y $3 \mathrm{~mm}\left(\mathrm{~F}_{3 \mathrm{~mm}}\right)$ para los tubos de la $1^{\mathrm{a}}$ y $2^{\mathrm{a}}$ serie, respectivamente (3). Sin embargo, este planteamiento no es el adecuado para tubos con 40 $\mathrm{kg} / \mathrm{m}^{3}$, pues no presentaron una caída del valor de $\mathrm{F}$ para el régimen de desplazamientos con el que se trabajó. En consecuencia, para estos tubos se evalúa sólo su carga $F_{u}$ y se da por sentado que su comportamiento post-rotura se adecua a los criterios establecidos para la clase C-90 (los tubos con $20 \mathrm{~kg} / \mathrm{m}^{3}$ ya cumplen los requisitos mínimos en régimen post-rotura).

En la Tabla 2 se presentan los valores individuales y medios de $F_{c r}, F_{1.2 \mathrm{~mm}}$ ( $1^{\mathrm{a}}$ serie), $F_{3 \mathrm{~mm}}$ ( $2^{\mathrm{a}}$ serie) y de $F_{\mathrm{u}}$ obtenidos experimentalmente. Los resultados de los
With respect to this aspect, it was observed that cracking began, in all cases, at the key of section A with values of $F_{c r}$ around $90 \mathrm{kN}$. On the other hand, in the pipes from the $2^{\text {nd }}$ series, it was observed that the appearance of the first cracks coincided with the change in the slope of the F-v curve. This change was not detected in the pipes from the $1^{\text {st }}$ series until the springline also cracked, a situation which took place when load $F$ reached average values of $126 \mathrm{kN}, 114 \mathrm{kN}$ and $138 \mathrm{kN}$ for the pipes with $10 \mathrm{~kg} / \mathrm{m}^{3}, 20 \mathrm{~kg} / \mathrm{m}^{3}$ and $40 \mathrm{~kg} / \mathrm{m}^{3}$, respectively. Therefore, it may be assured that if the measurement of $v$ is performed in section $A$, load $F_{C r}$ can be deduced from the F-v curve at the point where the first slope change takes place. On the other hand, if the measurement is performed as in the $1^{\text {st }}$ series, this procedure would lead to values of $F_{C r}$ on the side of insecurity, requiring a visual inspection in order to detect $F_{c r}$.

In the case of the pipes with low $C_{f}$ instability regions similar to those described in (3) were observed. They were reflected in the $F-v$ curves by means of an increase in the distance between points (see, for instance, the stretch between 1.5 and $3.0 \mathrm{~mm}$ of the pipes with 20 $\mathrm{kg} / \mathrm{m}^{3}$ from the $2^{\text {nd }}$ series).

Likewise, it was verified that the pipes fulfilled the strength requirements of class $C-90$ established in (15). Concretely, for pipes with a $D_{i}$ of $600 \mathrm{~mm}$ it is required to obtain a load $F_{C}$ of $36 \mathrm{kN} / \mathrm{m}$ and a load $F_{u}$ of $54 \mathrm{kN} / \mathrm{m}$ in the CT (90 kN and $135 \mathrm{kN}$, respectively, taking into account that the length of the pipes was $2500 \mathrm{~mm}$ ).

Regarding load $F_{\text {min,pos, }}$ established for $C-90(90 \mathrm{kN})$, it must be verified that the $F_{\text {max, pos }}$ measured in the curve $F$ $v$ is equal or higher than the former. The value of $v$ for which $F_{\text {max,pos }}$ is reached is function of, among other parameters, the diameter of the pipe and the amount and type of reinforcement; in other words, of the global stiffness of the pipe. For this paper it was established that $F_{\text {max,pos }}$ is reached for a $v$ of $1.2 \mathrm{~mm}\left(F_{1.2 \mathrm{~mm}}\right)$ and $3 \mathrm{~mm}$ $\left(F_{3 \mathrm{~mm}}\right)$ for the pipes from the $1^{\text {st }}$ and the $2^{\text {nd }}$ series, respectively (3). However, this is not the suitable approach in the case of pipes with $40 \mathrm{~kg} / \mathrm{m}^{3}$, since they did not show a drop of value $F$ for the displacement regime used in the tests. Consequently, in the case of those pipes only their load $F_{u}$ is assessed, and it is taken for granted that their post-failure behaviour fits in with the criteria established for class C-90 (the pipes with $20 \mathrm{~kg} / \mathrm{m}^{3}$ already fulfil the minimum requirements in post-failure regime).

Table 2 shows the individual and average values of $F_{c r}$ $F_{1.2 \mathrm{~mm}}\left(1^{\text {st }}\right.$ series), $F_{3 \mathrm{~mm}}\left(2^{\text {nd }}\right.$ series) and $F_{u}$ obtained experimentally. The results from pipes $T 3$ for the 
tubos T3 para las cuantías de $10 \mathrm{~kg} / \mathrm{m}^{3}$ y $20 \mathrm{~kg} / \mathrm{m}^{3}$ de la $1^{\text {a }}$ serie se rechazaron a causa de algunos desajustes que se produjeron durante la ejecución del ensayo.

En referencia a los valores recogidos en la Tabla 2, se desprende que los tubos de la $1^{\text {a }}$ serie presentaron cargas $F_{\mathrm{cr}}$ superiores a los $90 \mathrm{kN}$ estipulados para $\mathrm{F}_{\mathrm{c}}$ en la $\mathrm{C}-90$. Asimismo, los tubos de la $2^{\mathrm{a}}$ serie mostraron cargas medias de $F_{\mathrm{cr}}$ alrededor de los $94 \mathrm{kN}$, siendo también aprobados porque no fueron observados indicios de fisuración en la inspección visual al alcanzar $F_{\mathrm{C}}$, incluso, para los tubos T1 y T2 con cuantías de $40 \mathrm{~kg} / \mathrm{m}^{3}$ de la $2^{\mathrm{a}}$ serie, para los que la carga $\mathrm{F}_{\mathrm{cr}}$ fue de $80 \mathrm{kN}$.

En cuanto a la respuesta en rotura, los valores $F_{u}$ se obtuvieron para desplazamientos próximos a $0,3 \mathrm{~mm}$ para los tubos de la $1^{\text {a }}$ serie y a $1 \mathrm{~mm}$ para los de la $2^{\mathrm{a}}$ serie, corroborando así el comportamiento más rígido de los primeros. Se desprende de la Tabla 2 que, en valor medio, todos los tubos alcanzaron la carga de $135 \mathrm{kN}$ fijada para Fu excepto los tubos reforzados con $20 \mathrm{~kg} / \mathrm{m}^{3}$ y $10 \mathrm{~kg} / \mathrm{m}^{3}$ de fibras de la $1^{\mathrm{a}}$ y $2^{\mathrm{a}}$ serie, respectivamente. En ambos casos la carga media $\mathrm{F}_{\mathrm{u}}$ obtenida fue de $132 \mathrm{kN}$ (un 2\% menor a la requerida). Por último, se verifica que la carga $F_{\text {min,pos }}(90 \mathrm{kN})$ es superada por todos los tubos excepto para el tubo T2 con $10 \mathrm{~kg} / \mathrm{m}^{3}$ de fibras de la $2 a$ serie. En cualquier caso, los valores medios de $F_{1.2 \mathrm{~mm}}$ y de $F_{3 \mathrm{~mm}}$ son holgadamente superiores al $F_{\text {min,pos }}$ fijado para estos tubos, demostrándose que tanto el tipo de fibra como la cuantías empleadas son adecuadas para satisfacer el requisito resistente. amounts of $10 \mathrm{~kg} / \mathrm{m}^{3}$ and $20 \mathrm{~kg} / \mathrm{m}^{3}$ from the $1^{\text {st }}$ series were rejected due to some mismatches which occurred during the performance of the test.

Concerning the values gathered in Table 2, it is deduced that the pipes from the $1^{\text {st }}$ series showed loads $F_{c r}$ higher than the $90 \mathrm{kN}$ stipulated for $F_{C}$ in C-90. Likewise, the pipes from the $2^{\text {nd }}$ series showed average loads of $F_{c r}$ around $94 \mathrm{kN}$, which were also accepted since no cracking signs were observed during the visual inspection once $F_{c}$ was reached, not even in pipes $T 1$ and $T 2$ with amounts of $40 \mathrm{~kg} / \mathrm{m}^{3}$ from the $2^{\text {nd }}$ series, for which the load $F_{c r}$ was $80 \mathrm{kN}$.

As regards the response in failure, the values $F_{u}$ were obtained for displacements close to $0.3 \mathrm{~mm}$ for the pipes from the $1^{\text {st }}$ series and close to $1 \mathrm{~mm}$ for those from the $2^{\text {nd }}$ series, thus corroborating the stiffer behaviour of the former. It is deduced from Table 2 that, in average value, all the pipes reached the load of $135 \mathrm{kN}$ established for $F_{u}$ except the pipes reinforced with 20 $\mathrm{kg} / \mathrm{m}^{3}$ and $10 \mathrm{~kg} / \mathrm{m}^{3}$ of fibres from the $1^{\text {st }}$ series and the $2^{\text {nd }}$ series, respectively. In both cases the average load $F_{u}$ obtained was of $132 \mathrm{kN}$ (a $2 \%$ lower than required). Finally, it is verified that load $F_{\text {min, pos }}(90 \mathrm{kN})$ is exceeded by all the pipes except pipe $T 2$ with $10 \mathrm{~kg} / \mathrm{m}^{3}$ of fibres from the $2^{\text {nd }}$ series. In any case, the average values of $F_{1.2 \mathrm{~mm}}$ and $F_{3 \mathrm{~mm}}$ are higher than the $F_{\text {min,pos }}$ established for these pipes, proving that the type of fibres and the amounts used are the suitable ones to accomplish the strength requirements.

Tabla 2 / Table 2

Valores individuales y medios obtenidos experimentalmente. Individual and average values of $F$ experimentally obtained.

\begin{tabular}{|c|c|c|c|c|c|c|c|c|c|c|c|c|c|}
\hline \multirow{2}{*}{$\begin{array}{l}\text { Serie I } \\
\text { Series }\end{array}$} & \multirow{2}{*}{$\begin{array}{c}C_{f} \\
\left(\mathrm{~kg} / \mathrm{m}^{3}\right)\end{array}$} & \multicolumn{4}{|c|}{$F_{c r}(\mathrm{kN})$} & \multicolumn{4}{|c|}{$F_{u}(\mathrm{kN})$} & \multicolumn{4}{|c|}{$F_{1.2 \mathrm{~mm}}$ y $F_{3 m m}(\mathrm{kN})$} \\
\hline & & T1 & $\mathrm{T} 2$ & T3 & \begin{tabular}{|l} 
Medio I \\
Average
\end{tabular} & $\mathrm{T} 1$ & T2 & T3 & $\begin{array}{l}\text { Medio I } \\
\text { Average }\end{array}$ & T1 & T2 & T3 & $\begin{array}{c}\text { Medio I } \\
\text { Average }\end{array}$ \\
\hline \multirow{3}{*}{$1^{\mathrm{a}} / 1^{s t}$} & 10 & 96 & 98 & $n / a$ & 97 & 149 & 120 & $\mathrm{n} / \mathrm{a}$ & 135 & 107 & 94 & $\mathrm{n} / \mathrm{a}$ & 101 \\
\hline & 20 & 96 & 100 & $\mathrm{n} / \mathrm{a}$ & 98 & 140 & 124 & $\mathrm{n} / \mathrm{a}$ & 132 & 118 & 102 & $\mathrm{n} / \mathrm{a}$ & 110 \\
\hline & 40 & 93 & 98 & 100 & 97 & 156 & 163 & 149 & 156 & - & - & - & - \\
\hline \multirow{3}{*}{2 a $/ 2^{\text {nd }}$} & 10 & 100 & 83 & 100 & 94 & 127 & 132 & 138 & 132 & 97 & 88 & 98 & 94 \\
\hline & 20 & 98 & 95 & 85 & 93 & 151 & 145 & 129 & 142 & 121 & 120 & 108 & 116 \\
\hline & 40 & 80 & 80 & 115 & 92 & 152 & 140 & 193 & 162 & - & - & - & - \\
\hline
\end{tabular}

\section{SIMULACIÓN NUMÉRICA DEL ENSAYO DE APLASTAMIENTO}

Para la simulación numérica del EA se precisa una herramienta numérica que considere el comportamiento no lineal del material y la posibilidad de modelar la respuesta del HRFA. Para ello, se ha empleado el modelo Análisis de Secciones Simétricas (AES) descrito en $(16,17)$. Éste ya ha servido como apoyo numérico

\section{NUMERICAL SIMULATION OF CRUSHING TEST}

The numerical simulation of the CT requires a numerical tool capable to consider the nonlinear behaviour of the material and the possibility of modelling the response of SFRC. To this purpose, the Analysis of Evolutive Sections model (AES), described in $(16,17)$, was used. This model has already been used satisfactorily as a 
en otras aplicaciones (18). Por otra parte, se ha desarrollado el modelo MAP para la simulación del EA. Varias de las hipótesis aceptadas en el modelo MAP fueron sugeridas en (19).

Mediante el modelo AES se discretiza el hormigón en elementos tipo fibra y las barras de acero en elementos de área concentrada. Es sabido que la inclusión de fibras modifica el comportamiento a compresión del HRFA en función del volumen empleado (20). En este sentido, su respuesta a compresión uniaxial se describe con la expresión sugerida por en (21). Por otra parte, la simulación de su comportamiento a tracción se aborda mediante el modelo recogido en (11) porque éste ya ha sido empleado satisfactoriamente en otros trabajos $(22,23)$. El acero pasivo para armadura se modeliza con un diagrama trilineal con la posibilidad de endurecimiento.

Para la simulación a nivel estructural del EA se ha considerado la doble simetría del elemento $(B=0)$, por lo que se trabaja con un cuarto de tubo. Asimismo, se supone que la sección en clave y en hastiales son las que controlan el comportamiento del tubo. En ambas se concentran los fenómenos de fisuración y plastificación (modelados con la subrutina AES), mientras que en las secciones intermedias se acepta un comportamiento lineal de los materiales constituyentes. Se ha dividido la respuesta del tubo en tres fases: fase lineal elástica, fase elástica con fisuración en clave (ver Figura 1) y fase elástica con fisuración en clave y hastiales (ver Figura 1).

Las ecuaciones de gobierno del problema estructural implementadas en MAP fueron deducidas en (19) considerando que las solicitaciones normales son las determinantes. En este sentido, es sabido que el comportamiento frente a solicitaciones tangenciales de elementos de HRFA mejora notablemente (24), por lo que no es de esperar roturas a cortante en este tipo de tubos.

Teniendo en cuenta las 3 fases descritas anteriormente se puede simular la respuesta continua en el plano $\mathrm{F}-\mathrm{v}$ del tubo en el EA. Si bien, para que el modelo garantice resultados representativos del EA se requiere que el comportamiento del tubo sea rígido y que no aparezcan fisuras intermedias (exceptuando la de clave y hastiales). Este patrón es el que se ha observado en los tubos ensayados para esta campaña. Asimismo, también se ha observado en THFA de $800 \mathrm{~mm}$ de $D_{i}$ (3) y de $1.000 \mathrm{~mm}$ (2), por lo que se fija este último como el valor máximo del rango de aplicabilidad del modelo a falta de contrastación con mayores diámetros. numerical tool in other applications (18). On the other hand, the MAP model was developed for the simulation of the CT. Several of the hypotheses accepted in the MAP model were suggested in (19).

By means of the AES model the concrete is discretized into fibre-type elements and the steel bars, into concentrated area elements. It is well known that the addition of fibres modifies the compression behaviour of SFRC depending on the volume used (20). In this respect, its response to uniaxial compression is described by the expression suggested in (21). On the other hand, the simulation of its post-cracking behaviour is approached by means of the model gathered in (11), since it has already been successfully used in other works $(22,23)$. The passive steel for the reinforcement is modelled using a trilinear diagram.

For the simulation of the CT at a structural level, the double symmetry of the element $(B=0)$ was taken into account, hence only a quarter of pipe is modelled. Likewise, it is taken for granted that the key and springline sections are the ones which control the response of the pipe. The cracking and yielding phenomena (modelled with the AES subroutine) are concentrated in both sections, whereas in the intermediate sections a linear behaviour of the constituting materials is accepted. The response of the pipe has been divided into three stages: elastic linear stage, elastic stage with cracking at key (see Figure 1) and elastic stage with cracking at key and springline (see Figure 1).

The governing equations of the structural problem implemented in MAP were deduced in (19) considering that the bending and axial forces are the determinant ones. In this respect, it is well known that the shear strength of SFRC elements improves noticeably (24), so shear failures are not expected in this type of pipes.

Taking into account the three stages previously described, the curve F-v of the pipe in the CT can be obtained. However, the model guarantees representative results of the $C T$, provided that no intermediate cracks appear (rigid concrete pipes). This is the pattern observed in the pipes tested for this campaign. Likewise, it has also been observed in SFRCP with $D_{i}$ of $800 \mathrm{~mm}$ (3) and of $1000 \mathrm{~mm}$ (2), hence the latter is established as the maximum value of the applicability range of the model for lack of contrasting with larger diameters. 


\section{SIMULACIÓN DE LOS RESULTADOS EXPERIMENTALES CON MAP}

Para la modelización del comportamiento a compresión del HRFA se ha empleado el modelo sugerido en (21) fijando una resistencia fck de $50 \mathrm{MPa}$ (4). Por otra parte, para la simulación de su respuesta a tracción se ha recurrido al un diagrama propuesto en (11). Sin embargo, a falta de los ensayos de flexotracción necesarios (25) para poder determinar $f_{R, i}$ para cada $C_{f}$, se han empleado las expresiones recogidas en (26). En este sentido, el tipo de fibras utilizado tanto en esta campaña como en las empleadas para calibrar las expresiones presentadas en (26) son las DRAMIX ${ }^{\circledR}$ RC-80/60-BN.

En las Figuras 3 se presentan las curvas F-v obtenidas experimentalmente (valores individuales y medios) y numéricamente para los tubos con $C_{f}$ de 10,20 y $40 \mathrm{~kg} / \mathrm{m}^{3}$ de la $2^{a}$ serie. Se ha elegido esta serie porque se ha visto que las medidas experimentales de $v$ en la sección $A$ (Figura 1b) son más representativas del comportamiento global del tubo.

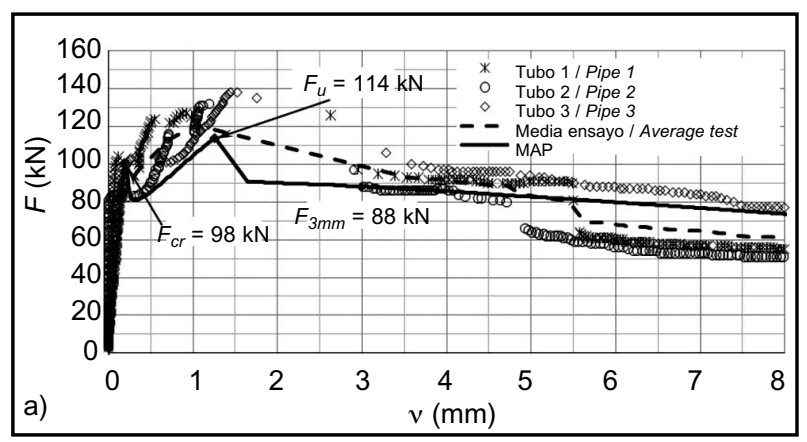

\section{SIMULATIONS OF THE EXPERIMENTAL RESULTS WITH MAP}

The model suggested in (21) was used for modelling the compression behaviour of SFRC, fixing a resistance $f_{c k}$ of $50 \mathrm{MPa}$ (4). On the other hand, the diagram proposed in (11) was used in order to simulate its linear and postcracking response. However, due to the lack of tests needed (25) in order to be able to determine $f_{R, i}$ for each $C_{f}$, the expressions proposed in (26) were used. In this respect, the type of fibres used in this campaign as well as those used in order to calibrate the expressions presented in (26) belong to the type DRAMIX ${ }^{\circledR} R C$ 80/60-BN.

Figures 3 show the curves F-v obtained experimentally (individual and average values) and numerically for the pipes with $C_{f}$ of 10,20 and $40 \mathrm{~kg} / \mathrm{m}^{3}$ from the $2^{\text {nd }}$ series. This series was selected because it was observed that the experimental measurements of $v$ in section $A$ (Figure 1b) are more representative of the global behaviour of the pipe.

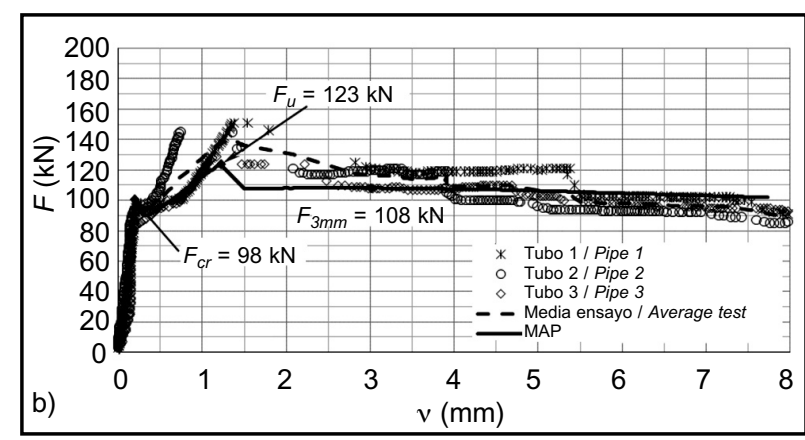

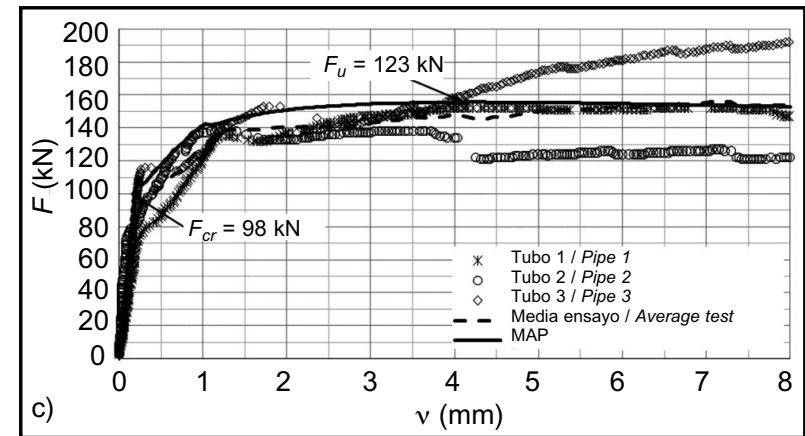

Figura 3. Curvas F-v para los tubos con (a) 10 , (b) 20 y (c) $40 \mathrm{~kg} / \mathrm{m}^{3}$ de fibras.

Figure 3. F-v curves for the pipes reinforced with (a) 10 , (b) 20 y (c) $40 \mathrm{~kg} / \mathrm{m}^{3}$ of fibres.

Complementariamente, en la Tabla 3 se recogen los valores experimentales y numéricos medios de $F_{c}, F_{u}$ y $F_{3 \mathrm{~mm}}$ reflejados en las Figuras 3 . El parámetro $\xi$ es el error relativo respecto al dato experimental. Valores positivos de $\xi$ indican que dato experimental excede al numérico y viceversa.
Complementarily, Table 3 gathers the average experimental and numerical values of $F_{c} F_{u}$ and $F_{3 \mathrm{~mm}}$ shown in Figures 3. The parameter $\xi$ is the relative error with regard to the experimental data. Positive values of $\xi$ indicate that the experimental data exceed the numerical one, and vice versa. 
Tabla 3 / Table 3

Valores medios experimentales y numéricos de $\mathrm{F}$ obtenidos en los tubos ensayados. Experimental (average) and numerical values of $F$ obtained with the tested pipes.

\begin{tabular}{|c|c|c|c|c|c|c|c|c|c|}
\hline \multirow{2}{*}{$\begin{array}{c}\text { Cuantía de } \\
\text { fibras / Fibre } \\
\text { dosage } \\
\left(\mathrm{kg} / \mathrm{m}^{3}\right)\end{array}$} & \multicolumn{3}{|c|}{$F_{c r}$} & \multicolumn{3}{|c|}{$F_{u}$} & \multicolumn{3}{|c|}{$F_{3 m m}$} \\
\hline & Exp. (kN) & $\operatorname{MAP}(\mathrm{kN})$ & $\xi(\%)$ & Exp. (kN) & MAP (kN) & $\xi(\%)$ & Exp. (kN) & MAP (kN) & $\xi(\%)$ \\
\hline 10 & 94 & 98 & -4.3 & 132 & 114 & 13.6 & 94 & 88 & 6.4 \\
\hline 20 & 93 & 98 & -5.4 & 142 & 123 & 13.4 & 116 & 108 & 6.9 \\
\hline 40 & 92 & 98 & -6.5 & 162 & 156 & 3.7 & - & - & - \\
\hline
\end{tabular}

A raíz de los resultados presentados en la Figura 3a, se desprende que el modelo MAP se ajusta bien a los resultados experimentales para la cuantía de $10 \mathrm{~kg} / \mathrm{m}^{3}$, particularmente en régimen lineal elástico y en régimen post-rotura. Para este último, los resultados numéricos para $v$ superiores a $7,5 \mathrm{~mm}$ tienden hacia los valores máximos experimentales. Los valores de $F_{c r}, F_{u}$ y $F_{3 m m}$ obtenidos numéricamente son 98 kN, 114 kN y 88 kN, respectivamente. Por lo tanto, debido a que ni $F_{\mathrm{u}}$ ni $\mathrm{F}_{3 \mathrm{~mm}}$ alcanzan los valores mínimos estipulados en (15) para la clase C-90, se puede afirmar que según el modelo la cuantía de $10 \mathrm{~kg} / \mathrm{m}^{3}$ es insuficiente para asegurar dicha clase.

Los resultados de la Figura 3b referentes a la dosificación de $20 \mathrm{~kg} / \mathrm{m}^{3}$, ponen de manifiesto que la simulación mediante el modelo MAP garantiza valores próximos a los experimentales. Si bien, el modelo sobreestima la respuesta resistente de los tubos para $v$ superiores a los $5,5 \mathrm{~mm}$. Esto puede indicar que los valores $f_{R, i}$ empleados para simular el comportamiento del HRFA traccionado son ligeramente mayores a los reales a partir de dicho límite. Los valores de $F_{c r}, F_{\mathrm{u}}$ y $F_{3 m m}$ obtenidos numéricamente son: 98 kN, 123 kN y 108 kN, respectivamente. Consecuente, tampoco se alcanzaría con $20 \mathrm{~kg} / \mathrm{m}^{3}$ la clase $\mathrm{C}-90$ debido a que la carga $\mathrm{F}_{\mathrm{u}}(123 \mathrm{kN})$ es inferior a los $135 \mathrm{kN}$ requeridos.

Por último, para los tubos con $40 \mathrm{~kg} / \mathrm{m}^{3}$ de fibras (Figura $3 c$ ), el modelo numérico se ajusta adecuadamente a los resultados experimentales en todas las etapas. En este caso, $F_{\mathrm{cr}}$ es de $98 \mathrm{kN}$ y $\mathrm{F}_{\mathrm{u}}$ de $156 \mathrm{kN}$, no aplicando en este caso la evaluación F3mm. Por consiguiente, el modelo también predice una respuesta resistente superior a la especificada para un tubo de $600 \mathrm{~mm}$ clase C-90 (15) con esta cuantía de fibras. En este sentido, se da por supuesto que la carga $F_{3 \mathrm{~mm}}$ es mayor que los $90 \mathrm{kN}$ fijados para $F_{\text {min,pos }}$ (con $20 \mathrm{~kg} / \mathrm{m}^{3}$, la $F_{3 \mathrm{~mm}}$ media ya es de $108 \mathrm{kN}$ ). Asimismo, el modelo pone de manifiesto, en consonancia con los resultados experimentales, la existencia de una rigidización del sistema al alcanzar la plastificación del tubo.

El análisis de los resultados presentados en la Tabla 3 permite deducir que:
From the results presented in Figure 3a, it can be deduced that the MAP model fits in properly with the experimental results for the amount of $10 \mathrm{~kg} / \mathrm{m}^{3}$, particularly both in elastic linear and post-failure stages. In the latter, the numerical results for $v$ higher than $7.5 \mathrm{~mm}$ tend toward the experimental maximum values. The values of $F_{C r}, F_{u}$ and $F_{3 m m}$ obtained numerically are $98 k N, 114 k N$ and $88 k N$, respectively. Therefore, since neither $F_{u}$ nor $F_{3 \mathrm{~mm}}$ reach the minimum values stipulated in (15) for class C-90, it can be stated that according to the model the amount of $10 \mathrm{~kg} / \mathrm{m}^{3}$ is not enough to guarantee strength class C-90.

The results from Figure $3 b$ concerning the dosage of 20 $\mathrm{kg} / \mathrm{m}^{3}$ highlight that the simulation by means of the MAP model guarantees values close to the experimental ones. Nonetheless, the model overestimates the load capacity of the pipes for $v$ higher than $5.5 \mathrm{~mm}$. This could indicate that the values $f_{R, i}$ used for the simulation of the behaviour of tensioned SFRC are slightly higher than the real ones for this range of displacements. The values of $F_{c r}, F_{u}$ and $F_{3 \mathrm{~mm}}$ obtained numerically are: $98 \mathrm{kN}, 123 \mathrm{kN}$ and $108 \mathrm{kN}$, respectively. Consequently, class C-90 will not be reached with $20 \mathrm{~kg} / \mathrm{m}^{3}$ either, since the load $F_{u}$ $(123 \mathrm{kN})$ is lower than the $135 \mathrm{kN}$ required.

Finally, in the case of the pipes with $40 \mathrm{~kg} / \mathrm{m}^{3}$ of fibres (Figure 3c), the numerical model fits in adequately with the experimental results at all stages. In this case, the value of $F_{C r}$ is $98 \mathrm{kN}$ and $F_{u}$ is $156 \mathrm{kN}$. Therefore, the model also predicts a strength capacity higher than that specified for a class C-90 pipe of $600 \mathrm{~mm}$ (15) with this amount of fibres. In this respect, it is taken for granted that the load $F_{3 \mathrm{~mm}}$ is higher than the $90 \mathrm{kN}$ established for $F_{\text {min,pos }}$ (with $20 \mathrm{~kg} / \mathrm{m}^{3}$, the average $F_{3 \mathrm{~mm}}$ is already $108 \mathrm{kN})$. Likewise, the model highlights, in accordance with the experimental results, the existence of hardening once the pipe yields.

From the analysis of the results presented in Table 3 it can be concluded that: 
- La carga $F_{c r}$ obtenida numéricamente es independiente de la cuantía de fibras. $\mathrm{F}_{\mathrm{cr}}$ depende exclusivamente de $f_{c t}$, del $D_{i}$ y de $h$ (2). Por otra parte, el modelo tiende a sobrevalorar Fcr respecto a los resultados experimentales entre un 4,3\% (tubo con 10 $\mathrm{kg} / \mathrm{m}^{3}$ ) y un $6,5 \%$ (tubo con $40 \mathrm{~kg} / \mathrm{m}^{3}$ ). Esto puede ser debido a la incorporación de agua adicional durante el amasado de agua adicional para aumentar la trabajabilidad de la mezcla en los tubos de la $2^{a}$ serie.

- El modelo infravalora $F_{\mathrm{u}}$ respecto a los valores experimentales entre un $3,7 \%$ (tubo con $40 \mathrm{~kg} / \mathrm{m}^{3}$ ) y un $13,6 \%$ (tubo con $10 \mathrm{~kg} / \mathrm{m}^{3}$ ). Cuando se alcanza $F_{\mathrm{u}}$ la matriz de hormigón ya ha fisurado, la razón de esta diferencia obtenida puede deberse a que la ecuación constitutiva del HRFA traccionado sea conservadora para los niveles de $v$ en los que se alcanza $F_{u}$. En este sentido, en (2) se comprueba que las fibras trabajan prácticamente orientadas paralelamente al flujo de tensiones cuando se emplean los métodos convencionales de fabricación de tubos. Por lo tanto, éstas trabajan con una gran eficiencia. Un modo alternativo de considerar este hecho a nivel de cálculo sería emplear la metodología sugerida en (27), por ejemplo.

- En referencia a la carga $F_{3 \mathrm{~mm}}$, se obtienen valores numéricos un $6,4 \%\left(10 \mathrm{~kg} / \mathrm{m}^{3}\right)$ y un $6,9 \%\left(20 \mathrm{~kg} / \mathrm{m}^{3}\right)$ inferiores en comparación con los datos experimentales. Ello se debería, igual que para la carga $\mathrm{F}_{\mathrm{u}}$, a la infravaloración de los parámetros involucrados en la definición de la ecuación constitutiva elegida (11) para modelar la respuesta a tracción del HRFA.

Teniendo en cuenta lo anteriormente mencionado, se puede afirmar que el modelo MAP se ajusta satisfactoriamente a los resultados experimentales aun habiendo empleado una ecuación constitutiva para modelar el comportamiento a tracción del HRFA calibrada a partir de hormigones con fck de entre 25 y $30 \mathrm{MPa}$ (26) frente a los $50 \mathrm{MPa}$ obtenidos en el hormigón utilizado para los tubos de esta campaña. Asimismo, la ecuación constitutiva no tiene en cuenta el efecto de la orientación preferente de las fibras dentro de la pared del tubo, que en este caso es favorable. Consiguientemente, en la mayoría de los casos el modelo MAP tiende a infravalorar los resultados experimentales, siendo estas diferencias del $7 \%$ en valor medio $y$, en cualquier caso, no superiores al $13,6 \%$. En definitiva, la buena correlación obtenida puede considerarse un éxito teniendo en cuenta la multitud de variables involucradas en el problema, la incertidumbre de muchas de éstas y la dificultad de la determinación experimental directa de alguna de ellas.

\section{CONCLUSIONES}

En este artículo se ha presentado un trabajo referente a aspectos tecnológicos y de simulación numérica de THFA. Se han mostrado los resultados obtenidos en una
- The load $F_{c r}$ obtained numerically is independent from the amount of fibres. $F_{c r}$ depends exclusively on $f_{c t} D_{i}$ and $h$ (2). On the other hand, the model tends to overestimate $F_{c r}$ with respect to the experimental results between a $4.3 \%$ (pipe with $10 \mathrm{~kg} / \mathrm{m}^{3}$ ) and a $6.5 \%$ (pipe with $40 \mathrm{~kg} / \mathrm{m}^{3}$ ). This could be due to the incorporation of additional water during the mixing in order to increase the workability of the mixture in the pipes from the $2^{\text {nd }}$ series.

- The model underestimates $F_{u}$ with regard to the experimental values between a $3.7 \%$ (pipe with 40 $\mathrm{kg} / \mathrm{m}^{3}$ ) and a $13.6 \%$ (pipe with $10 \mathrm{~kg} / \mathrm{m}^{3}$ ). When $F_{u}$ is reached, then the reason for the difference obtained could be the constitutive equation used to simulate the post-cracking behaviour of SFRC being too conservative for the levels of $v$ at which $F_{u}$ is reached. In this respect, in (2) it is verified that the fibres work practically oriented parallel to the flow of stresses when the conventional pipe manufacturing methods are used. Therefore, they work with a high efficiency. An alternative way of considering this fact at the level of calculation would be using the methodology suggested in (27), for example.

- With regard to $F_{3 \mathrm{~mm}}$ the numerical values obtained are a $6.4 \%\left(10 \mathrm{~kg} / \mathrm{m}^{3}\right)$ and a $6.9 \%\left(20 \mathrm{~kg} / \mathrm{m}^{3}\right)$ lower in comparison with the experimental data. This could be due, just as in the case of load $F_{u}$ to the underestimation of the parameters involved in the definition of the constitutive equation chosen (11) to model the post-cracking response of SFRC.

Taking into account what has been previously mentioned, it can be assured that the MAP model adjusts satisfactorily to the experimental results, even though a constitutive equation was used in order to model the post-cracking behaviour of SFRC, calibrated from concretes with $f_{c k}$ ranging from 25 to $30 \mathrm{MPa}$ (26) as opposed to the $50 \mathrm{MPa}$ obtained in the concrete used for the pipes in this campaign. Likewise, the constitutive equation does not take into account the effect of the preferential orientation of the fibres within the thickness of the pipe, which in this case is favourable. Consequently, in most of the cases the MAP model tends to underestimate the experimental results, these differences being of a $7.0 \%$ in average value and, in any case, not higher than $13.6 \%$. Then, the good correlation obtained can be considered to be a success taking into account the multitude of variables involved in the problem, its uncertainty, and the difficulty of the experimental determination of some of them.

\section{CONCLUSIONS}

This article has introduced a work related to the technological aspects and the numerical simulation of SFRCP. It also showed the results obtained in an 
campaña experimental de 18 tubos de $600 \mathrm{~mm}$ de diámetro de HRFA con cuantías de fibras de 10,20 y 40 $\mathrm{kg} / \mathrm{m}^{3}$ de los que se derivan las siguientes conclusiones:

- La fabricación de este tipo de elementos es posible mediante los sistemas tradicionales modificando in situ, si es necesario, la humedad de la mezcla. Los tiempos de producción y la mano de obra se reducen considerablemente respecto a la solución con armadura tradicional.

- Se confirma que el ensayo continuo con control de los desplazamientos por LVDTs, en sustitución del cíclico, conduce a resultados representativos del comportamiento resistente de este tipo de tubos.

- La carga $F_{c r}$ observada en una inspección visual es similar independientemente de la cuantía de fibras y método de medida. La primera fisura apareció, en todos los casos, en la cara interna de la clave de la zona del macho. Para los tubos de la $2^{\mathrm{a}}$ serie, el punto donde se produce el primer cambio de pendiente de la curva $\mathrm{F}-\mathrm{v}$ coincide con $\mathrm{F}_{\mathrm{cr}}$, tal como se produce en las simulaciones numéricas.

- Los tubos con $40 \mathrm{~kg} / \mathrm{m}^{3}$ presentan endurecimiento de la curva F-v cuando se produce la fisuración global del tubo (clave y hastiales). Se desprende de este hecho que las fibras pueden desarrollar en estos elementos una tarea similar al de las barras tradicionales, incluso, con una respuesta frente a la fisuración mejor en régimen de servicio.

- La carga crítica para alcanzar los requisitos resistentes de la C-90 para este tipo de tubos es $\mathrm{F}_{\mathrm{u}}$.

A continuación, se ha presentado las bases principales del modelo MAP desarrollado para el análisis de THFA. El grado de correlación experimentación-modelo se considera satisfactorio, habiendo arrojado el modelo resultados del lado de la seguridad con un error relativo medio del $7 \%$. Para mejorar la bondad de los resultados, se propone ajustar la ecuación constitutiva del HRFA traccionado para tener en cuenta la orientación preferente de las fibras.

En consecuencia, el modelo MAP puede emplearse como método de diseño para otros diámetros (iguales o inferiores a los $1.000 \mathrm{~mm}$ ), otros espesores y otras clases resistentes sin la necesidad de ensayar varios tubos para tantear la dosificación óptima de fibras, sino sólo para verificar el diseño resultante. Ello supondría un ahorro significativo de tiempo y recursos económicos cuando no se tiene un patrón de dosificación establecido, ya sea porque se ha cambiado alguna característica geométrica o bien porque se trata de una clase resistente poco frecuente para dicho diámetro.

En la actualidad hay en marcha varias campañas experimentales con el fin de tener un mayor banco de datos con el que contrastar y ajustar el modelo. experimental campaign with 18 SFRC pipes with diameters of $600 \mathrm{~mm}$ and amounts of fibres of 10,20 and $40 \mathrm{~kg} / \mathrm{m}^{3}$. The following conclusions were derived from those results:

- The manufacturing of this type of elements is possible by means of the traditional systems modifying in situ, if necessary, the water content of the mixture. The manufacturing time and the labour force are reduced considerably with respect to SBRCP.

- It is confirmed that the continuous test with displacement control by means of LVDTS, as a replacement for cyclical tests, leads to results representative of the strength capacity of this sort of pipes.

- The load $F_{c r}$ observed during the visual inspection is similar regardless of the amount of fibres and the measuring method. The first crack appeared, in all cases, in the internal face of the key (in section A). In the case of the pipes from the $2^{\text {nd }}$ series, the point where the first change in the slope of curve F-v occurs coincides with $F_{c r}$, exactly as in the numerical simulations.

- The pipes with $40 \mathrm{~kg} / \mathrm{m}^{3}$ show hardening of the curve F-v when global cracking of the pipe (key and springline) occurs. From this fact it is deduced that in these elements the fibres can perform a task similar to that of the traditional bars, even with an improved response to cracking in in-service regime.

- The load which is critical in order to fulfil the strength requirements of class $C-90$ for this type of pipes is $F_{u}$.

Moreover, the main bases of the MAP model, developed for the analysis of SFRCP, were introduced. The degree of correlation between experimentation and simulation is considered to be satisfactory, since the model gave results on the side of security with an average relative error of $7.0 \%$. In order to improve the accuracy of the results, it is proposed to adjust the constitutive equation of post-cracked SFRC so that it takes into account the preferential orientation of the fibres.

Consequently, the MAP model can be used as a design method for other diameters (equal or lower than 1000 $\mathrm{mm})$, other thickness and other strength classes, without the need for testing several pipes in order to estimate the optimal dosage of fibres, but only to verify the resulting design. This would mean a significant saving of time and economic resources when there is no established dosage pattern, be it because some geometrical characteristic has been changed, or because it is a strength class uncommon for such a diameter.

Currently, several experimental campaigns are being carried out with the aim of contributing to a larger data bank to contrast and adjust the model. 


\section{AGRADECIMIENTOS}

Los autores de este documento quieren poner de manifiesto su agradecimiento por el apoyo económico recibido vía el Proyecto de Investigación BIA2010-17478: Procesos constructivos mediante hormigones reforzados con fibras.

Asimismo, el profesor Antonio D. de Figueiredo agradece el apoyo de CAPES - Coordenação de Aperfeiçoamento de Pessoal de Nível Superior- por haberle otorgado la beca postdoctoral que le permitió su participación en este trabajo.

\section{ACKNOWLEDGEMENTS}

The authors of this document wish to express their appreciation for the financial support received through the Research Project BIA2010-17478: Procesos constructivos mediante hormigones reforzados con fibras.

Likewise, Professor Antonio D. de Figueiredo wishes to thank the support provided by CAPES - Coordenação de Aperfeiçoamento de Pessoal de Nível Superior- for having awarded him the postdoctoral grant that allowed him to participate in this work.

\section{APÉNDICE. NOMENCLATURA / APENDIX. NOMENCLATURE}

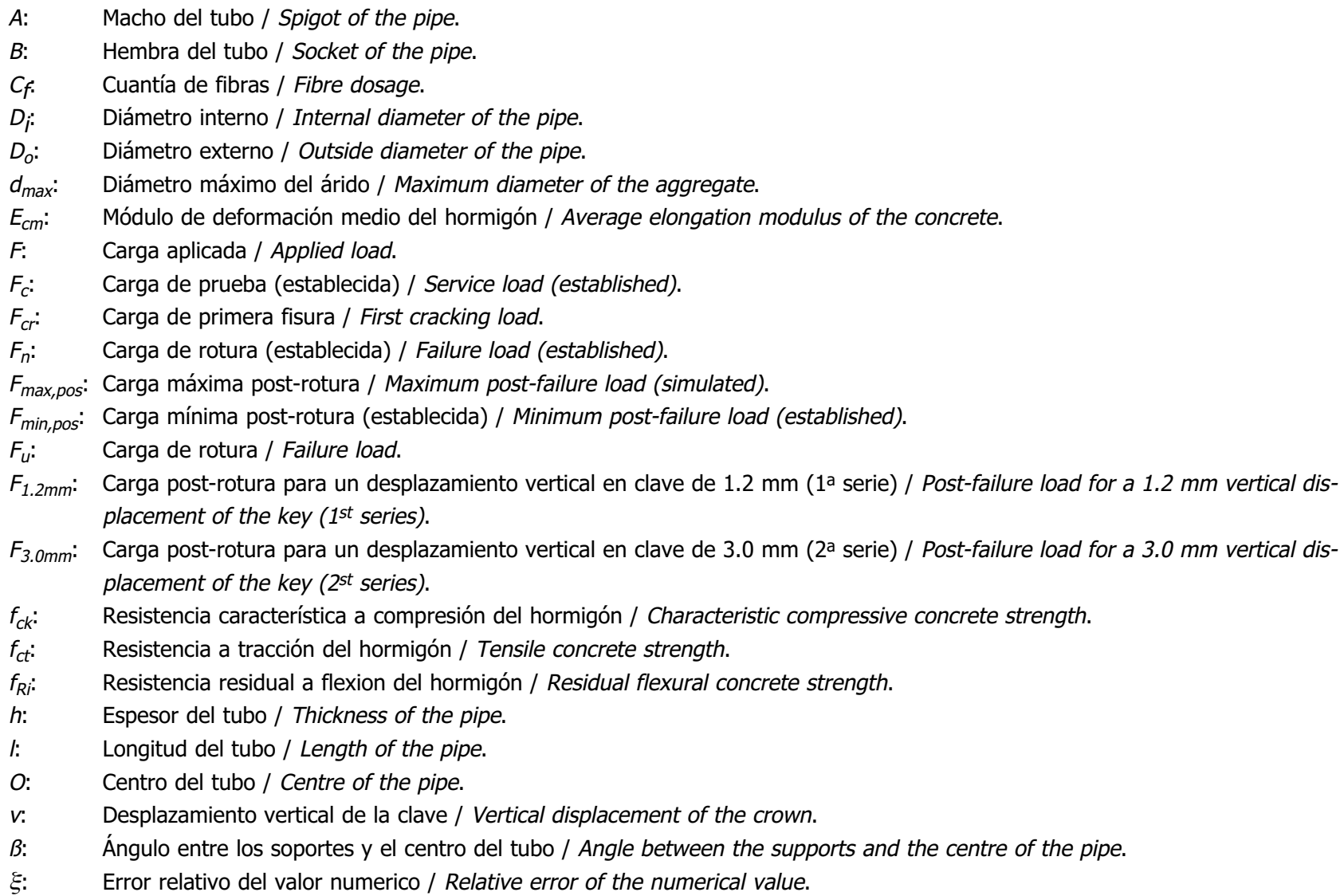

\section{BIBLIOGRAFÍA / BIBLIOGRAPHY}

(1) Haktanir, T.; Ari, K.; Altun F.; Karahan O.: "A comparative experimental investigation of concrete, reinforced-concrete and steel-concrete pipes under three-edge-bearing test", Construction and Building Materials 2007, 21(8), 1702-8, doi:10.1016/j.conbuildmat.2006.05.031 (2) de la Fuente, A.; Armengou J.: "Aplicaciones estructurales del HRFA: Tubos de saneamiento, paneles de cerramiento y placas de suelo reforzado", Aplicaciones estructurales del HRFA, Jornada Técnica 2007-JT-02, 9 de Octubre de 2007, Barcelona (Spain), UPC, 2007.

(3) Figueiredo, A. D de.: "Evaluation of the test method for crushing strength of steel fiber reinforced concrete pipes", 7th International RILEM Symposium on Fibre Reinforced Concrete, Chennai, India, 2008, Fiber Reinforced Concrete: Design and Applications, Babneux France, RILEM Publications SARL 2008, 1:989-1000.

(4) Figueiredo, A. D de; Chama Neto, P. J.: "Avaliação de desempenho mecânico de tubos", Revista DAE 2008, 178, 34-9. 
(5) Aa'ad, S.; Saxer, A.: "Influence of Fiber Geometry on the Flexural Strength Performance of Steel Fiber Reinforced Concrete (SFRC)", Fibre Concrete 2007, Prague, Czech Republic, 2007.

(6) Chiaia, B.; Fantilli, A. P.; Vallini, P.: "Evaluation of crack width in FRC structures and application to tunnel linings", RILEM Materials and Structures 2009, 42(3), 339-51, doi:10.1617/s11527-008-9385-7.

(7) Blanco, A.; Pujadas, P.; de la Fuente, A.; Aguado, A.: "Análisis comparativo de los modelos constitutivos del hormigón reforzado con fibras", Hormigón y Acero 2010; 61(256),83-100.

(8) Parrot, J.: "Estudio de la sostenibilidad en tuberías de saneamiento", Tesina de especialidad, UPC, Barcelona (Spain), 2009.

(9) Hilleborg, A.; Modéer, M.; Petersson, P. E.: "Analysis of crack formation and crack growth in concrte by means of fracture mechanics and finite elements", Cem. Concr. Res., 1976, 6, 773-82.

(10) Laranjeira, F.: "Design-oriented constitutive model for steel fiber reinforced concrete?. PhD Thesis, UPC, Barcelona (Spain), 2010.

(11) Vandewalle, L. et al: "Test and design methods for steel fibre reinforced concrete: $\sigma-\varepsilon$ design method. Final recommendation", RILEM Materials and Structures 2003, 36(262), 560-67, doi:10.1617/14007.

(12) Silva J. L. da; el Debs, M. K.: "Influência da bolsa no comportamento estrutural de tubos de concreto armado submetidos à compressão diametral", In: $51^{\circ}$ Congresso Brasileiro do Concreto, 2009, Curitib (Brazil), pp. 1-13.

(13) UNE-EN 1916:2002. "Concrete pipes and fittings, unreinforced, steel fibre and reinforced", 2002.

(14) Moreno, E.; Fernández, M.: "Mix design of steel fiber reinforced concrete", Mater. Construc. 1997, 47(247-248),11-26, doi:10.3989/mc.1997.v47.i247-248.

(15) UNE 127916. "Tubos y piezas complementarias de hormigón en masa, de hormigón con fibra de acero y de hormigón armado", Complemento nacional a la norma UNE-EN 1916:2003, 2004.

(16) de la Fuente, A.; Aguado, A.; Molins, C.: "Modelo numérico para el análisis no lineal de secciones prefabricadas construidas evolutivamente", Hormigón y Acero 2008, 57(247), 69-87.

(17) de la Fuente, A.; Aguado, A.; Molins, C.: "Diseño óptimo integral de tubos de hormigón", Hormigón y Acero 2010; 61(259).

(18) Klein, N.; de la Fuente, A.; Aguado, A.; Masó, D.: "Hormigón ligero autocompactante con fibras para rehabilitación de forjados", Mater. Construcc., vol 61, no 302, pp. 239-256. doi: 10.3989/mc2011.55.509.

(19) Pedersen, C.: "New production processes, materials and calculation techniques for fiber reinforced concrete pipes", PhD thesis, Department of Structural Engineering and Materials, Technical University of Denmark, 1996.

(20) Bencardino, F.; Rizzuti, L.; Spadea, G.; Swamy, R. N.: "Stress-strain behavior of steel fiber-reinforced concrete in compression", ASCE Journal of Materials in Civil Enineering 2008, 20(3),255-63, doi:10.1061/(ASCE)0899-1561(2008)20:3(255).

(21) Barros, J. A. O.; Figueiras, J. A.: "Flexural behaviour of SFRC: Testing and modelling", ASCE Journal of Materials in Civil Enineering 1999, 11(4), 331-9. doi:10.1061/(ASCE)0899-1561(1999)11:4(331).

(22) Blanco, A.: "Durabilidad del Hormigón con Fibras de Acero", Tesina de especialidad, UPC, Barcelona (Spain). 2008.

(23) Pujadas, P.: Durabilidad del Hormigón con Fibras de Polipropileno. Tesina de especialidad, UPC, Barcelona (Spain). 2008.

(24) Turmo, J.; Banthia, N.; Gettu, R.; Barragán, B.: "Study of the shear behaviour of fibre reinforced concrete beams", Mater. Construcc. 2008, 58(292), 5-13, doi:10.3989/mc.2008.40507.

(25) Vandewalle, L. et al: "Test and design methods for steel fibre reinforced concrete: Bending test (final recommendation)", RILEM Materials and Structures 2002, 35(253), 579-82, doi:10.1617/13884.

(26) Barros, J. A. O.; Cunha, V. M. C. F.; Ribeiro, A. F; Antunes, J. A. B.: "Post-cracking behaviour of steel fibre reinforced concrete", RILEM Materials and Structures 2005, 38(1), 47-56, doi:10.1007/BF02480574.

(27) Laranjeira, F.; Molins, C.; Aguado, A.: "Predicting the pullout reponse of inclined hooked steel fibers", Cem. Concr. Res. 2010, 40(10), 1471-87, doi:10.1016/j.cemconres.2010.05.005. 